\title{
26. MEASUREMENTS OF THE PERMEABILITY OF THE SHEETED DIKES IN HOLE 504B, ODP LEG 111
}

\author{
Keir Becker ${ }^{2}$
}

\begin{abstract}
An inflatable drill-string packer was used to measure the in-situ bulk permeability of two zones deep in Hole 504B, within the sheeted dikes that comprise the deepest $500-600 \mathrm{~m}$ of the hole. Previous measurements by Anderson and Zoback (1982), Zoback and Anderson (1983), and Becker et al. (1983a, 1983b) had shown that the upper $200 \mathrm{~m}$ of pillow lavas in the hole is fairly permeable, at about $10^{-14}-10^{-13} \mathrm{~m}^{2}$. In contrast, Anderson et al. (1985a, 1985b) measured a much lower bulk permeability of about $10^{-17} \mathrm{~m}^{2}$ over an interval of $>700 \mathrm{~m}$ that includes the deeper $400 \mathrm{~m}$ of extrusives and the upper $300 \mathrm{~m}$ of sheeted dikes. During Leg 111, the packer was inflated first at $936 \mathrm{mbsf}$, within the transition between extrusives and sheeted dikes, isolating the upper $470 \mathrm{~m}$ of dikes. Later in the leg, the packer was inflated at $1236 \mathrm{mbsf}$, isolating over $300 \mathrm{~m}$ of deeper dikes. At both depths standard slug tests were conducted, with excellent results. These results indicate that the sheeted dikes have bulk permeabilities on the order of $10^{-18}$ to $10^{-17} \mathrm{~m}^{2}$, comparable to the value measured by Anderson et al. (1985a, 1985b) in the deeper extrusives and upper sheeted dikes. Thus, except for the permeable upper $200 \mathrm{~m}$ of pillow lavas, most of the $1287.8 \mathrm{~m}$ of basaltic basement cored in Hole 504B is relatively impermeable.
\end{abstract}

\section{INTRODUCTION}

Hole 504B is by far the deepest hole yet drilled into the oceanic crust and is the only borehole that clearly penetrates through the extrusive lavas and into the underlying sheeted dikes predicted from studies of ophiolites. Hole 504B now extends to a total depth of $1562.3 \mathrm{~m}$ below seafloor (mbsf), penetrating $274.5 \mathrm{~m}$ of sediments, roughly $575 \mathrm{~m}$ of extrusive basaltic lavas, and about $200 \mathrm{~m}$ of transition into over $500 \mathrm{~m}$ of the underlying layer of intrusive basaltic sheeted dikes (Fig. 1). The hole therefore provides a unique opportunity to obtain "ground truth" to test our models of the state of the upper oceanic crust, including the key hydrogeologic property-permeability-that is the subject of this study.

The bulk porosity and permeability of the basaltic oceanic crust probably depend on irregular fractures and voids of uncertain scale, which cannot be represented by dredged or cored samples. Given present technology, the crustal porosity and permeability are best measured in situ from deep boreholes, preferably over intervals large enough to include the full effects of irregular fracture porosity. I report here the methods, data, and preliminary results of two such in-situ packer experiments, which were conducted during Leg 111 of the Ocean Drilling Program (ODP) to assess the bulk permeability of the sheeted dikes section penetrated by Hole 504B.

\section{SITE LOCATION AND PREVIOUS PERMEABILITY MEASUREMENTS}

Hole 504B is about $200 \mathrm{~km}$ south of the Costa Rica Rift in thickly sedimented $5.9-\mathrm{m}$.y.-old crust under $3460 \mathrm{~m}$ of seawater (Fig. 2). The site was located where the rapidly accumulating sediments impede active hydrothermal circulation in the crust. As a result, the conductive heat flow at the seafloor approaches the value of about $200 \mathrm{~mW} / \mathrm{m}^{2}$ predicted by plate tectonic theory. The temperature log of Gable et al. (this volume) shows a

\footnotetext{
${ }^{1}$ Becker, K., Sakai, H., et al., 1989. Proc. ODP, Sci. Results, 111: College Station, TX (Ocean Drilling Program).

2 Division of Marine Geology and Geophysics, Rosenstiel School of Marine and Atmospheric Science, University of Miami, Miami, FL 33149.
}

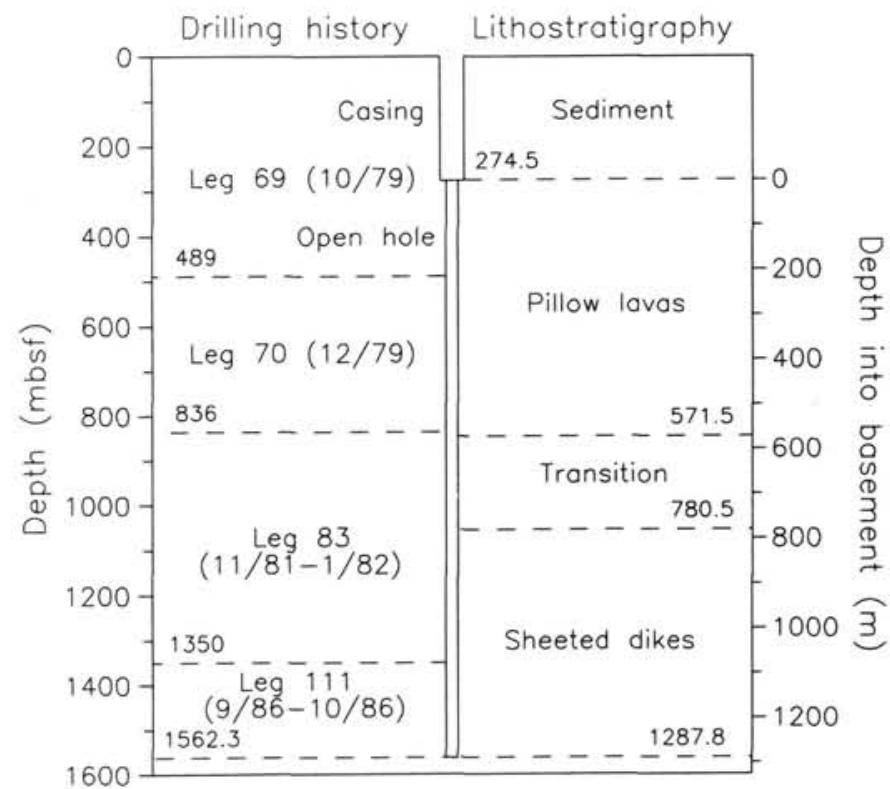

Figure 1. Schematic of the drilling history and lithostratigraphy of Hole 504B.

puzzling reduction of conductive heat flow deep in the hole and indicates that the in-situ temperature is about $165^{\circ} \mathrm{C}$ at the present total depth of the hole, $1562.3 \mathrm{mbsf}$.

During the four legs of the Deep Sea Drilling Project (DSDP) that visited Hole 504B before ODP Leg 111, an extensive set of downhole measurements was conducted to investigate the hydrogeology of the crust at the site, including permeability measurements using packers and various logs sensitive to porosity. As Figure 3 illustrates, the only significantly permeable zone in Hole 504B is the uppermost $200 \mathrm{~m}$ of pillow lavas, in which a permeability on the order of $10^{-14}$ to $10^{-13} \mathrm{~m}^{2}$ was measured using a packer by Anderson and Zoback (1982) and Zoback and Anderson (1983). This section generally corresponds to an underpressured zone of high permeability and porosity into which ocean bottom water has been sucked since the hole was drilled 


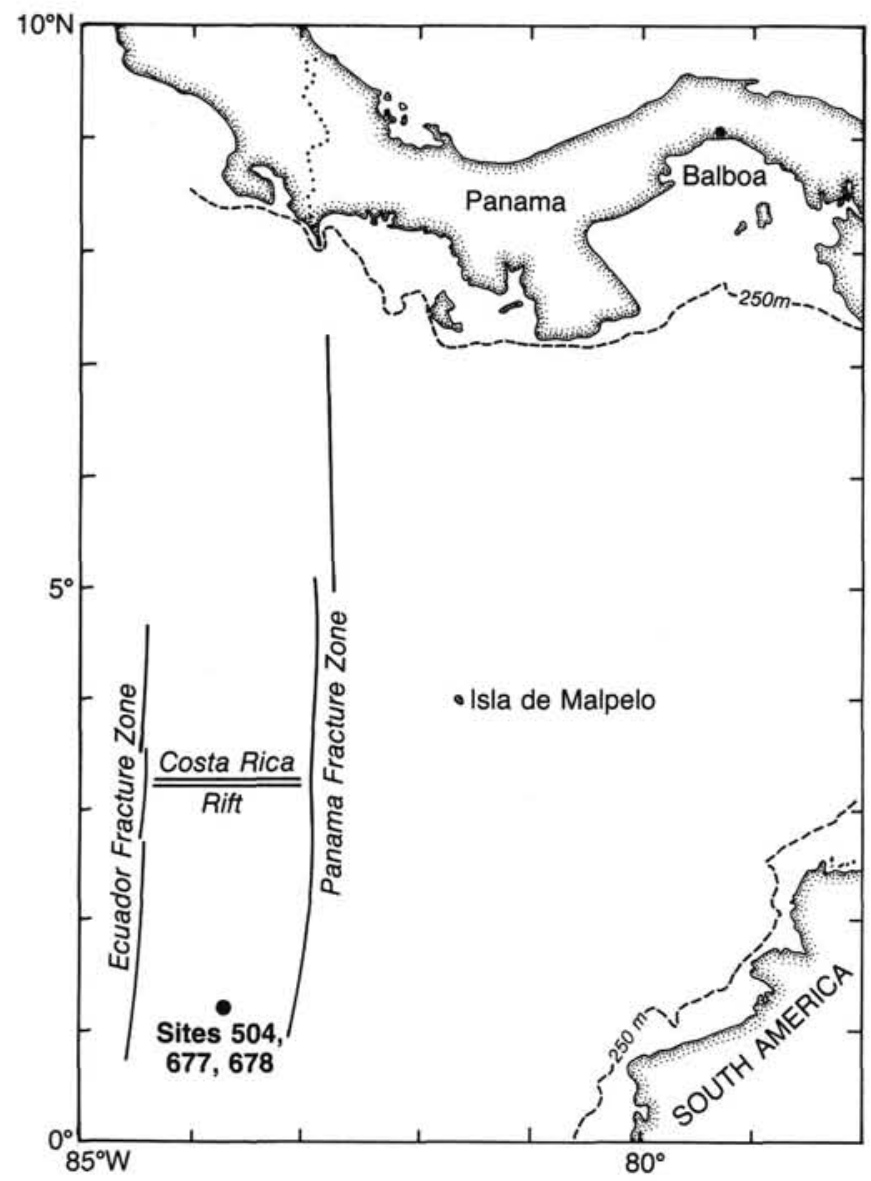

Figure 2. Location of Hole 504B in the eastern equatorial Pacific Ocean.

(Anderson and Zoback, 1982; Becker et al., 1983a, 1983b); this zone may also correspond to seismic Layer 2A (Anderson et al., 1982; Becker et al., 1982).

During DSDP Leg 83, Anderson et al. (1985a, 1985b) set a packer below this permeable section and measured an average permeability three orders of magnitude lower $\left(10^{-17} \mathrm{~m}^{2}\right)$ in the deeper pillow lavas, transition zone, and upper sheeted dikes between 536.5 and 1287.5 mbsf. Figure 3 shows that this section encompasses two zones of different average bulk porosities estimated from a long-spaced resistivity experiment (Becker et al., 1982; Becker, 1985). Based on these results, Becker et al. (1983b) and Anderson et al. (1985a, 1985b) speculated that there might be an empirical relationship between the permeability of the basaltic crust and porosity estimated from resistivity and suggested that the permeability in the low-porosity sheeted dikes might be orders of magnitude lower than the relatively low average value measured between 536.5 and 1287.5 mbsf.

\section{METHODS-PACKER EXPERIMENTS}

When Leg 111 returned to Hole 504B, a top priority was to measure the in-situ permeability of the low-porosity sheeted dikes-a formation that characterizes the oceanic crust, but has been sampled in-situ only in Hole 504B. Documenting the permeability of this section would also provide a test of the hypothesis that there might be an empirical relationship between permeability, which is difficult to measure, and porosity estimated from logs of resistivity or other properties.

\section{Choice of Inflation Depths}

The two depths at which the packer was inflated during Leg 111 were selected to allow determination of the bulk permeability of two overlap-

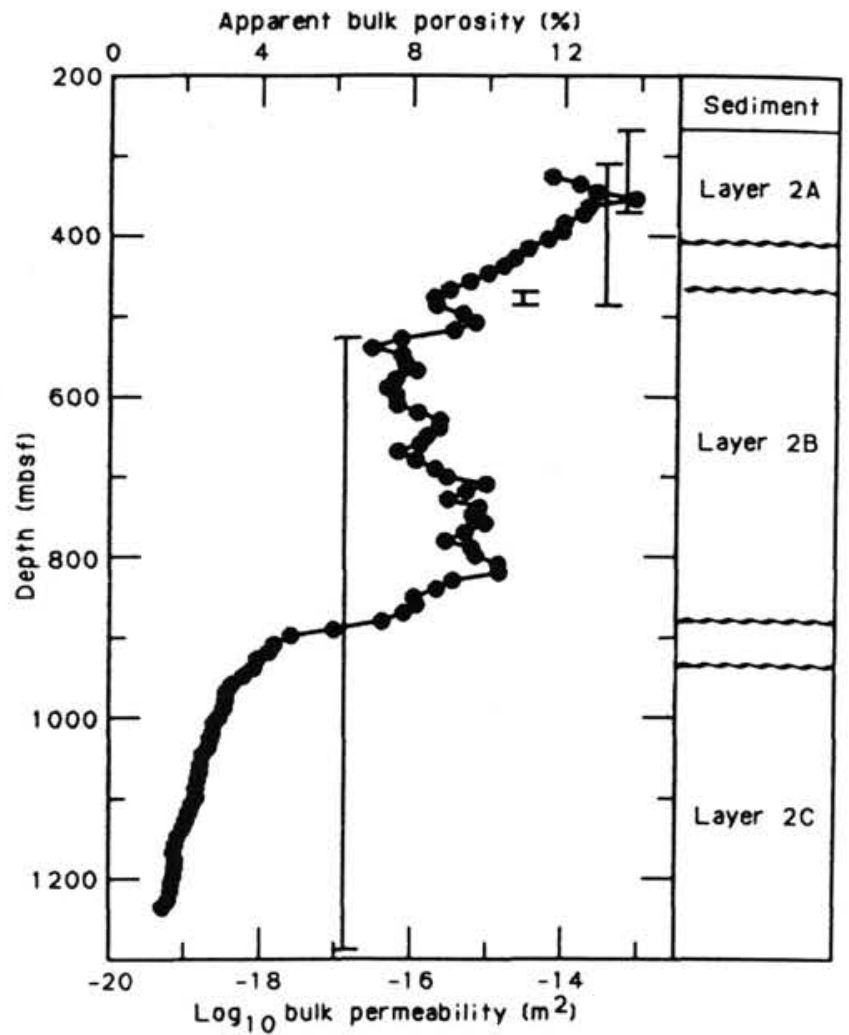

Figure 3. Bulk permeabilities (vertical bars) measured in Hole 504B before Leg 111 revisited the hole, plotted with apparent bulk porosities (dots) estimated from a long-spaced electrical resistivity experiment. The vertical extents of the bars indicate the intervals over which average permeabilities were measured; the horizontal extents of the bars indicate the estimated uncertainties in the permeability values. The scaling between porosity and permeability was chosen arbitrarily to emphasize the possibility of an empirical relation.

ping intervals, each consisting of a few hundred meters between the respective inflation depths and the bottom of the hole. After the hole had been drilled to $1406.5 \mathrm{mbsf}$, the packer was inflated at $936 \mathrm{mbsf}$, isolating $470.5 \mathrm{~m}$ of the upper sheeted dikes. The depth of $936 \mathrm{mbsf}$ was selected because it is barely deeper than both the reduction in porosity at about 900 mbsf (Fig. 3) and the stockworklike mineralization at 911929 mbsf that probably marks a formerly permeable but sealed interval within the transition between extrusives and underlying sheeted dikes (Alt et al., 1985, 1986). After the hole was drilled to $1547.5 \mathrm{mbsf}$, the packer was inflated at $1236 \mathrm{mbsf}$, isolating 311.5 of deeper sheeted dikes, well below the overlying transition zone.

\section{Equipment and Procedures}

The permeability of these two intervals was measured using a resettable drill-string packer manufactured by TAM International and described by Becker $(1986,1988)$. This packer incorporates inflatable rubber elements to isolate a section of the hole, and it can be configured as a single-element or a straddle packer. For the measurements in Hole $504 \mathrm{~B}$, it was configured with a single element and used to isolate the zone between the bottom of the hole and the seal (Fig. 4A). Because insitu temperatures approach $150^{\circ} \mathrm{C}$ at the depths at which the packer was set, the packer was assembled with special elements constructed with a high-temperature rubber rated for use to $120^{\circ} \mathrm{C}$. These elements performed well for one setting each, but were damaged on deflation and had to be changed between packer inflations.

The packer is actuated using a go-devil that free-falls down the drill string into the packer inflation subassembly, where a rubber seal on the go-devil directs seawater pumped from the ship into the inflatable packer elements. Once the packer elements are fully inflated and gripping the borehole, the packer holds the bottom-hole assembly (BHA) in the hole, and the drill-string heave compensator is adjusted to transfer 
A
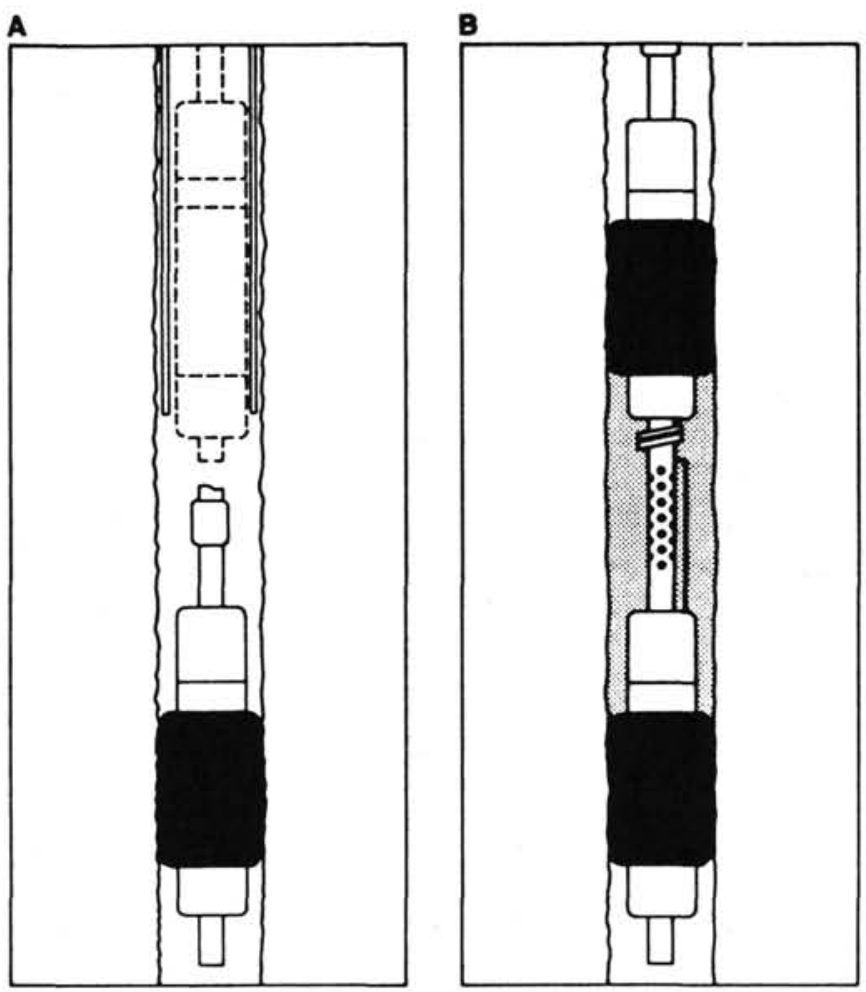

Figure 4. Sketches of inflatable drill-string packers. A. Single-element packer similar to that used during Leg 111 to isolate the formation between the inflation element and the bottom of the hole. B. Straddle packer, which isolates the zone between the elements.

and maintain 10,000-20,000 lb of weight (in the form of drill collars in the BHA immediately above the packer) onto the inflated packer. This weight shifts a sleeve in the inflation subassembly downward, closing the inflation-deflation port to the packer elements and opening the interval isolated by the packer to fluid pressure or flow applied by the shipboard pumps. As this occurs, some of the inflation pressure is applied to the formation as a pulse, which may be utilized as a slug test. However, in some instances, such as the first packer inflation during Leg 111, as the packer is set some part of the pressure may also be vented back up the annulus above the packer, and the pressure pulse "felt" in the isolated zone may not behave as a proper slug test.

The go-devil also carries pressure recorders (in this case, two carefully calibrated mechanical Kuster K-3 recorders) to monitor downhole fluid pressures in the isolated, pressurized zone during the experiment. While it would have been possible to include a one-way check valve in the go-devil to restrict the pressurized zone to exactly the zone isolated by the packer, no such check valve was used during Leg 111. Therefore, the fluids in the entire drill string as well as the isolated zone were pressurized during testing, and a pressure transducer at the rig floor was also used to provide a real-time indication of downhole events. The actual volumes of pressurized fluid and isolated borehole given in Table 1 are important in the calculation of permeability. Volumes and rates of fluids pumped into the isolated zone were monitored by recording changes in the volume of the pump reservoir, with an accuracy of \pm 0.1 bbl $\left(0.016 \mathrm{~m}^{3}\right)$.

Before the packer was set, the drill string was filled with seawater, and air was vented from the drill string and the plumbing connecting it to the pump. Then the integrity of the closed system was tested to $15-20$ $\mathrm{MPa}$, over twice the pressure applied during any of the permeability measurements. Once the packer was set, pressure pulse or slug tests were used to determine the permeability of the isolated interval, which was expected to be quite impermeable based on the results of permeabilities measured during previous legs. The methods used were similar to those described by Anderson and Zoback (1982), Zoback and Anderson (1983), Hickman et al. (1984), and Anderson et al. (1985a, 1985b) in measuring permeability in Holes $395 \mathrm{~A}$ and 504B with a different drill-string packer.
Table 1. Properties of the fluids in the zones pressurized during the Leg 111 slug tests, as used in the calculations presented in this paper.

\begin{tabular}{lll}
\hline & \multicolumn{2}{c}{ Slug tests } \\
\cline { 2 - 3 } \multicolumn{1}{c}{ Fluid property } & \multicolumn{1}{c}{$1-4$} & \multicolumn{1}{c}{$5-6$} \\
\hline Isolated zone (mbsf) & $936-1406.8$ & $1236-1547.5$ \\
Isolated volume $\left(\mathrm{m}^{3}\right)$ & 23.86 & 15.78 \\
a Pressurized volume $\left(\mathrm{m}^{3}\right)$ & 61.03 & 55.47 \\
b Average temperature $\left({ }^{\circ} \mathrm{C}\right)$ & 140 & 150 \\
b Dynamic viscosity $\left(10^{-4} \mathrm{~Pa}-\mathrm{s}\right)$ & 1.97 & 1.85 \\
\hline & & \\
\hline & & \\
a Total pressurized volumes include the isolated zones, drill \\
string, and rig-floor plumbing. \\
b Average temperature and dynamic viscosity apply to the flu- \\
ids in the isolated zone.
\end{tabular}

\section{Slug Test Procedures}

The slug tests were conducting following the methods for the "modified" slug test of Bredehoeft and Papadopulos (1980), which is an adaptation of the slug test method of Cooper et al. (1967) and Papadopulos et al. (1973) for formations with relatively low permeabilities. The modified slug test involves applying a short pressure pulse to the fluid in the zone isolated by the packer and monitoring the decay of this pulse as fluid flows from the borehole into the isolated formation.

The decay of such a pressure pulse is analogous to the decay of the frictional heating pulse on penetration of an oceanographic heatflow probe into sediments (Bullard, 1954; Carslaw and Jaeger, 1959) and is described by virtually the same equation (Cooper et al., 1967; Bredehoeft and Papadopulos, 1980):

$$
P(t) / P_{0}=F(\alpha, \beta) .
$$

Here, $P$ is pressure in excess of an initial reference value (hydrostatic in this case), $P_{0}$ is the initial pressure increase, $\alpha$ is a dimensionless parameter that depends on the storage coefficient $(S)$ and porosity $(\phi)$ of the isolated formation, $\beta$ is a dimensionless parameter that depends on the transmissivity $(T)$ and permeability $(k)$ of the formation, and $F$ is a complicated infinite integral. More specifically,

$$
\begin{aligned}
\alpha & =\pi a^{2} S / V_{\mathrm{w}} C_{\mathrm{w}} \rho_{\mathrm{w}} g \\
\beta & =\pi T t / V_{\mathrm{w}} C_{\mathrm{w}} \rho_{\mathrm{w}} g \\
S & =b \phi C_{\mathrm{i}} \rho_{\mathrm{i}} g \\
T & =b k \rho_{\mathrm{i}} g / \mu,
\end{aligned}
$$

where $t$ is time; $g$ is gravitational acceleration; $a$ is the radius of the hole in the isolated zone; $b$ is the height of the isolated zone; $C_{\mathrm{i}}, \rho_{\mathrm{i}}$, and $\mu$ are respectively the compressibility, density, and dynamic viscosity of the fluid in the isolated zone; and $C_{\mathrm{w}}$ and $\rho_{\mathrm{w}}$ are the compressibility and density of the fluid in the total pressurized volume $V_{\mathrm{w}}$. The function $F(\alpha, \beta)$ is given by

$$
F(\alpha, \beta)=\left(8 \alpha / \pi^{2}\right) \int_{0}^{\infty} \mathrm{du} \exp \left(\beta u^{2} / \alpha\right) / u f(u, \alpha),
$$

where $f(u, \alpha)=\left[u J_{0}(u)-2 \alpha J_{1}(u)\right]^{2}+\left[u Y_{0}(u)-2 \alpha Y_{1}(u)\right]^{2}, u$ is the variable of integration, and $J_{0}, J_{1}, Y_{0}$, and $Y_{1}$ are Bessel functions of the first and second kind.

To process the pressures measured during slug tests, we followed the standard curve-fitting method described by Cooper et al. (1967) and Papadopulos et al. (1973), as follows. The pressures measured during a slug test were first corrected for the extrapolated decay(s) of any previous slug test(s), using the approximation for $F(\alpha, \beta)$ valid at long times, which is proportional to $1 / t$. This approximation becomes reasonable after the pressure pulse decays to about one-third of its initial value (fig. 3 of Cooper et al., 1967), a condition that was met or closely approached by all of the slug tests conducted during Leg 111. A plot of corrected pressures vs. log time was superposed on a family of type curves of $F(\alpha, \beta)$ vs. $\log \beta$ calculated for various values of $\alpha$ spanning several orders of magnitude. The data plot was then shifted along the abscissa of the type-curve plot to visually determine the value of $\alpha$ for which the data best fit the type curve. Then the transmissivity and average permeability of the tested interval could be calculated from the cor- 
respondence between the values of time and $\beta$ for the best-fit curve, using the definitions for $\beta$ and transmissivity listed.

To justify the application of this theory for an instantaneous pressure pulse to real slug test data, the rise time of the slug test should be short compared to the decay time. For each slug test conducted during Leg 111, the ship's cement pump was used to inject a small volume or slug of seawater into the drill string (which was already full of seawater at hydrostatic pressure), and the decay of the resultant pressure pulse was monitored with the downhole and rig-floor recorders. Typically, 200-1000 L was pumped into the drill string in $0.5-1 \mathrm{~min}$ to produce a pulse with an initial pressure rise on the order of $3 \mathrm{MPa}$ in the isolated zone. Because the sheeted dikes in Hole 504B are relatively impermeable, these pressures pulses decayed very slowly and smoothly, justifying the assumption that they were applied effectively instantaneously.

\section{ASSUMPTIONS, APPROXIMATIONS, AND SOURCES OF ERROR AND UNCERTAINTY}

\section{In-Situ Permeability vs. Calculated Bulk Permeability}

Slug tests involve an important assumption-that the permeability of the rock in the zone isolated by the packer is uniform and isotropic. This assumption is probably not valid for the sheeted dikes, where permeability may be dominated by fractures and large-scale interconnected porosity at irregular scales. Nevertheless, it probably becomes more valid as the scale of the permeability tests (i.e., the length of the zone isolated by the packer) increases with respect to the spacing of the fractures (Parsons, 1966; Hickman et al., 1984). The permeabilities computed here are Darcian or equivalent porous-media permeabilities, denoted as bulk permeabilities, obtained by applying the theory for uniformly permeable media. If the in-situ permeability is indeed dominated by isolated fractures, the actual hydraulic conductivities of such fractures may be orders of magnitude greater than the transmissivities reported here.

\section{Integrity of the Packer Seal}

The validity of results obtained with a packer obviously depends on the hydraulic integrity of the seal made with the inflatable elements. However, given that the annulus of an ODP hole is open to an infinite reservoir of seawater at hydrostatic pressure, it would be extremely difficult to sense any possible upward leakage of fluids past the inflation element(s). If a packer isolates an impermeable zone, as occurred deep in Hole 504B during Leg 111, serious leakage past it would be obvious in the pressures measured in the isolated zone. However, relatively minor leakage might not be apparent in the measured pressures, but could seriously affect the calculations of permeability and transmissivity. No indications of such leakage were observed in the pressures measured downhole, which showed very slow, smooth decay curves for the slug tests. Nevertheless, it is possible that very slight leakage could have occurred, which would result in calculated transmissivities and permeabilities greater than the real values. Therefore, the values calculated here must be considered upper bounds on the relatively low transmissivities and bulk permeabilities of the zones isolated in Hole 504B.

\section{Model-Fitting Procedures}

In processing slug tests, the bulk permeability is derived from parameters determined from the best fit of measured pressures to those predicted by models valid for isotropically permeable formations. As noted by Cooper et al. (1967), Papadopulos et al. (1973), and Hickman et al. (1984), the calculated typecurves are fairly similar over a wide range in values of $\alpha$, and significant errors in the choice of $\alpha$ are likely in the curvematching procedure. Fortunately, the large errors possible in determining $\alpha$ result in reasonably small corresponding errors in the determination of transmissivity and permeability. Thus, this procedure yields relatively poor estimates of the storage coeffi- cient and porosity, but better determinations of transmissivity and average permeability.

The analysis for slug tests involves subjectively fitting measured pressures to the type curves, with no rigorous assessment of possible errors. In interpreting past slug test results in crystalline formations, Anderson and Zoback (1982), Zoback and Anderson (1983), Haimson and Doe (1983), Hickman et al. (1984), and Anderson et al. (1985a, 1985b) estimated uncertainties on the order of $\pm 30 \%$ in calculated transmissivities and bulk permeabilities, by deliberately misfitting the type curves by an order of magnitude in $\alpha$. We follow a similar procedure here, but use increments of half an order of magnitude in $\alpha$ at the larger values of $\alpha$ where the differences in the shapes of the type curves are greater.

\section{Properties of the Fluids in the Pressurized System}

The equations listed previously demonstrate that the transient pressures measured during slug tests depend on the properties of the pressurized fluids, particularly viscosity and compressibility, which vary with both temperature and pressure. For the temperature-dependent viscosity of seawater, we follow Anderson et al. (1985a, 1985b) in using Gartling's (1977) equation, $\mu\left(10^{-3} \mathrm{~Pa}-\mathrm{s}\right)=16.68 T^{-0.8987}$, with $T$ in ${ }^{\circ} \mathrm{C}$. For average in-situ temperatures of $140^{\circ}-150^{\circ} \mathrm{C}$ in the zones tested during Leg 111 , this yields a viscosity of about $0.2 \times 10^{-3} \mathrm{~Pa}-\mathrm{s}$ (Table 1), which was used for the calculations reported here.

As noted by Neuzil (1982), the compressibility of the fluid in a shut-in hole is sometimes greater than that of the pure fluid (seawater in this case), because of (1) compliance of the drill string and test equipment and (2) air possibly trapped in the system. While every effort was made during Leg 111 to purge all air from the drill string, pump, and connecting plumbing, it was possible that air remained in the system. Such trapped air would affect the system compressibility and the calculated transmissivity and bulk permeability, which are directly proportional to the compressibility. As recommended by Neuzil (1982), during slug tests the pumped volumes were carefully recorded to determine the effective compressibility of the pressurized fluid system by the definition of compressibility: $C=\mathrm{d} V / V \mathrm{~d} P$. Our results (Table 2), like Neuzil's (1982), showed actual compressibilities

Table 2. System compressibilities determined from the pressure increases measured in the isolated zones during the slug tests conducted in Hole 504B.

\begin{tabular}{lccc}
\hline Slug & Volume & Peak downhole & Calculated \\
test & pumped & pressure increase \\
no. & $\left(\mathrm{m}^{3}\right)$ & $(\mathrm{MPa})$ & $\begin{array}{c}\text { compressibility } \\
\left(10^{-9} \mathrm{~Pa}^{-1}\right)\end{array}$
\end{tabular}

Packer set at $936 \mathrm{mbsf}$

$\begin{array}{cccc}1 & \mathrm{n} / \mathrm{a} & 3.637 & \mathrm{a}(3.06) \\ 2 & 0.937 & 3.348 & 4.59 \\ 3 & 0.381 & 2.962 & 2.11 \\ 4 & 0.413 & 2.719 & 2.49 \\ \text { Average } & \text { value }( \pm \text { standard deviation) } & 3.06 \pm 1.33\end{array}$

Packer set at 1236 mbsf

$\begin{array}{cccc}5 & \mathrm{n} / \mathrm{a} & 4.509 & { }^{\mathrm{a}}(0.72) \\ 6 & 0.175 & 4.369 & 0.72\end{array}$

a The system compressibility cannot be calculated for the first slug tests at both packer sets, because each of these slug tests occurred at the final stage in inflating the packer, and it is impossible to distinguish the volume of fluid actually pumped into the formation from the volume pumped into the packer. For these two slug tests, the parenthesized values of compressibility derived from the subsequent slug tests were used. 
on the order of 2-10 times the tabulated values for seawater. Transmissivities and bulk permeabilities reported here are presented for two different values of compressibility, the measured values and the tabulated value for seawater (about $4 \times 10^{-10}$ $\mathrm{Pa}^{-1}$ ) used by Anderson and Zoback (1982), Zoback and Anderson (1983), and Anderson et al. (1985a, 1985b) in calculating permeabilities in the shallower section of Hole 504B.

\section{RESULTS}

\section{Downhole Pressure Records}

Figure 5 shows annotated pressures recorded in the isolated zones during both packer experiments. These plots and the subsequent analyses are based on about 500 points read from each original 5 - by $10-\mathrm{cm}$ analog record, using a microscopic caliper with a resolution of 0.0001 in., or about $4 \mathrm{kPa}$ on the pressure axis. These records show the smooth, slow decays of slug tests characteristic of low transmissivities and permeabilities.

The records are spiky during the times when the packer was being inflated, because of slight leakage past a go-devil seal, the only function of which is to direct fluids pumped from the rig
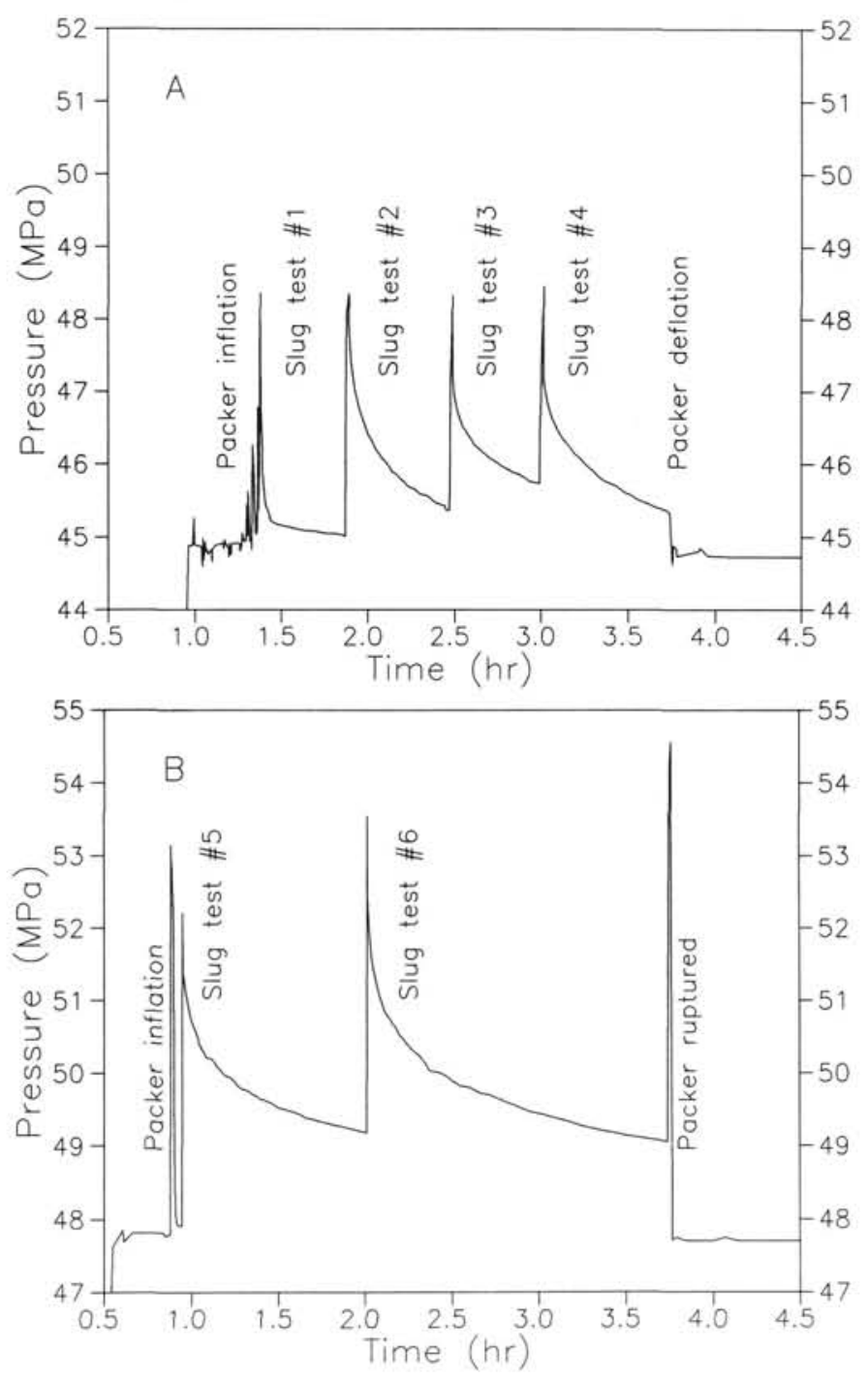

Figure 5. Pressures vs. time recorded in the zones isolated during the two packer inflations in Hole 504B. A. Packer inflation at 936 mbsf. B. Packer inflation at 1236 mbsf. floor into the packer elements during inflation. By maintaining pump pressure for 5-15 min, enough fluid was pumped into the elements for adequate inflation despite the leakage. As part of the normal procedure to lock the packer in the inflated position, the go-devil was then shifted to a position in which this seal was completely within the isolated zone and was not required to function; the leaky seal then had no effect on pressures applied to the formation during slug tests.

\section{Testing with the Packer Inflated at 936 mbsf}

As Figure 5A shows, four slug tests were conducted while the packer was inflated at 936 mbsf. The first slug test resulted from the packer inflation procedure and decays in an irregular manner; as previously described, it probably is not a valid slug test because of some temporary venting of pressure back up the annulus as the packer was set. The pressure pulses from slug tests 2-4 decay smoothly and fit the type curves quite well (Figs. 6B6D), after being corrected for the extrapolation(s) of the decay(s) of any previous slug test(s) (Figs. 7A-7C). Using the measured compressibilities, slug tests $2-4$ yield an average transmissivity of about $0.6 \times 10^{-6} \mathrm{~m}^{2} / \mathrm{s}$ and a permeability of $9-39 \times$ $10^{-18} \mathrm{~m}^{2}$ for the sheeted dikes between 936 and $1406.8 \mathrm{mbsf}$ (Table 3).

\section{Testing with the Packer Inflated at 1236 mbsf}

As Figure 5B shows, two slug tests were conducted while the packer was inflated at 1236 mbsf. The pressure pulses from both slug tests 5 and 6 decay smoothly and fit the type curves fairly well (Figs. 6E and 6F); slug test 6 first required correction for the extrapolated decay of slug test 5 (Fig. 7D). Using the system compressibility measured during slug test 6 , the two slug tests yield a transmissivity of about $0.1 \times 10^{-6} \mathrm{~m}^{2} / \mathrm{s}$, and a permeability of about $5 \times 10^{-18} \mathrm{~m}^{2}$ for the sheeted dikes between 1236 and 1547.5 mbsf (Table 3).

\section{SUMMARY OF PERMEABILITY DATA IN HOLE 504B}

Figure 8 shows the full set of permeability measurements from Hole 504B, plotted as in Figure 3 with the profile of apparent bulk porosity determined from the large-scale resistivity experiment conducted during Leg 83 (Becker et al., 1982; Becker, 1985; see also Pezard et al., this volume, for discussion of porosities determined from a similar log run during Leg 111). Bulk permeabilities in Hole 504B span a range of nearly five orders of magnitude, from the permeable value of $10^{-13}$ to $10^{-14} \mathrm{~m}^{2}$ calculated from injection and slug tests in the upper pillow lavas to the quite impermeable value of $4 \times 10^{-17}$ to $5 \times 10^{-18} \mathrm{~m}^{2}$ calculated from slug tests deep in the sheeted dikes. A similar range of bulk permeabilities was also measured in DSDP Hole $395 \mathrm{~A}$ (Hickman et al., 1984; Becker, in press), where much of the extrusive section is orders of magnitude more permeable $\left(10^{-14} \mathrm{~m}^{2}\right)$ than a massive zone deep in the hole.

Measured permeabilities and apparent bulk porosities both strongly decrease with depth in Hole 504B (Fig. 8). However, while the porosities fall into three major layers-upper pillow lavas, deeper extrusives, and sheeted dikes - the permeabilities fall into only two zones, the permeable upper $200 \mathrm{~m}$ of extrusives and the relatively impermeable lower kilometer of the cored section. In particular, the low permeability value in the interval that spans the deeper extrusives (about $500-900 \mathrm{mbs}$ ) is not consistent with the porosities estimated from resistivities in this section. This inconsistency seems to refute speculation by Becker et al. (1983b) and Anderson et al. (1985a, 1985b) that permeabilities in the oceanic crust might be predictable from logged estimates of bulk and/or fracture porosities. However, the permeabilities throughout the hole are more consistent with more refined estimates of fracture porosities derived from resis- 

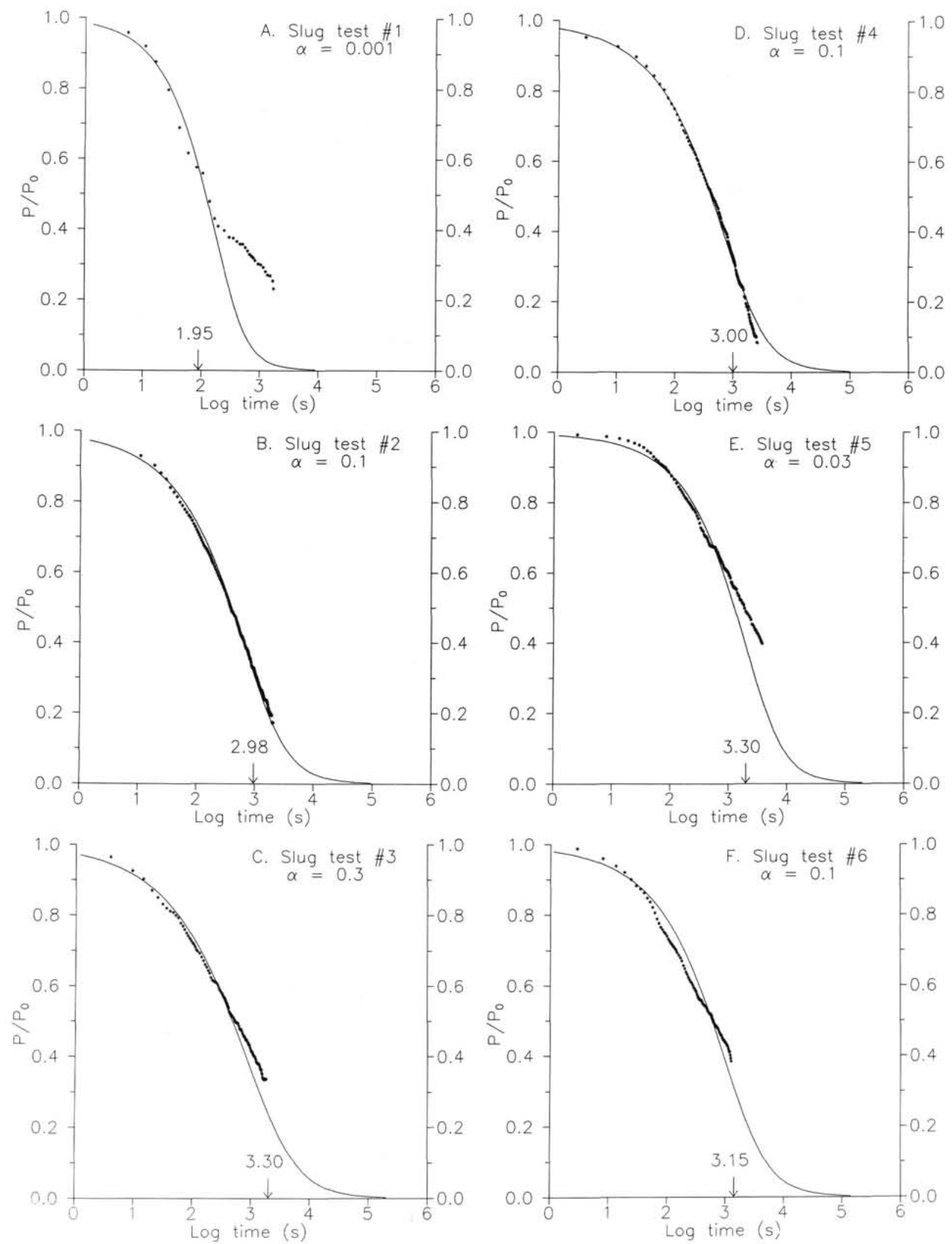

Figure 6. Best fits of the pressures recorded during slug tests to the type curves of Cooper et al. (1967). In each plot, the arrow and number pointing to the abscissa indicate the amount (given as log time, with time in seconds) that the type curve was shifted to obtain the best fit. The quantity $t_{1}$ used in calculating permeability and transmissivity is given by 10 raised to this exponent. A-D. Slug tests 1-4 at 936 mbsf. E-F. Slug tests 5-6 at 1236 mbsf. 

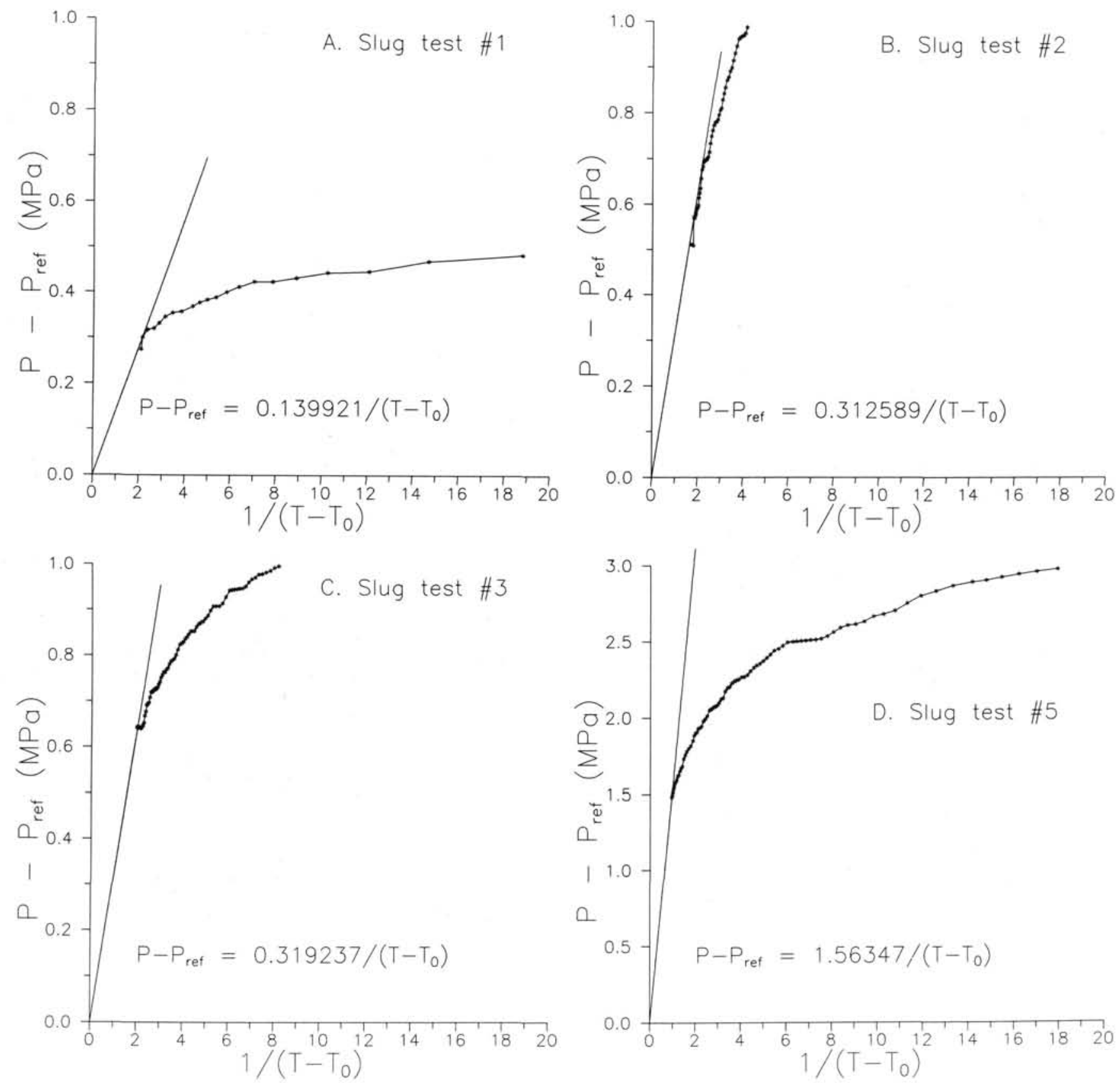

Figure 7. Pressures measured near the ends of slug tests (asterisks), compared to the $1 /$ time approximations (straight lines) to the $F(\alpha, \beta)$ function that were used to correct pressures during subsequent slug tests. For each slug test, $T_{0}$ is the time at which the pressure pulse was applied and $P_{\text {ref }}$ is a reference pressure defined as hydrostatic plus the superposed extrapolations of any previous slug tests.

tivities after accounting for the enhanced electrical conduction of alteration products in the deeper extrusives (Pezard et al., this volume).

Taken at face value, the low permeability values for the three relatively impermeable intervals in the bottom kilometer of the hole suggest the possibility that the deeper extrusives may be slightly less permeable than the transition zone and upper sheeted dikes (Fig. 8). However, this may be due to the difference in values used for compressibility, to which the permeability calculated from a slug test is directly proportional. In particular, for the slug tests in the interval from 536.5 to 1287.5 mbsf, Anderson et al. (1985a, 1985b) used the tabulated value of compressibility, which is considerably lower than the values actually mea- sured during the Leg 111 experiments, and therefore, their calculated permeability is lower than the permeability shown for the interval from 936 to 1406.8 mbsf (Fig. 7).

As part of this study, the DSDP drilling records were searched for the data required to calculate the actual compressibility during the experiments of Anderson et al. (1985a, 1985b), but the critical volumes of fluids pumped during their slug tests were not recorded and the actual compressibility could not be determined. If the actual compressibility during their measurements was higher than the tabulated value, as was observed by Neuzil (1982), it is possible that their calculated permeability value for the interval from 536.5 to 1287.5 mbsf is biased too low. If so, there would be a better correspondence between the actual per- 
Table 3. Summary of calculations of bulk permeabilities and transmissivities from results of slug tests conducted in Hole 504B during Leg 111.

\begin{tabular}{|c|c|c|c|c|c|c|}
\hline \multirow{2}{*}{$\begin{array}{l}\text { Slug } \\
\text { test } \\
\text { no. }\end{array}$} & \multirow{2}{*}{$\begin{array}{c}{ }^{\text {a}} \text { Type } \\
\text { curve } \\
\alpha\end{array}$} & \multirow{2}{*}{$\begin{array}{l}b_{t_{1}} \\
(s)\end{array}$} & \multicolumn{2}{|c|}{$\begin{array}{l}\text { 'Permeability } \\
\left(10^{-18} \mathrm{~m}^{2}\right)\end{array}$} & \multicolumn{2}{|c|}{$\begin{array}{l}{ }^{\text {CTransmissivity }} \\
10^{-6} \mathrm{~m}^{2} / \mathrm{s} \text { ) }\end{array}$} \\
\hline & & & $\mathrm{C}_{\text {meas }}$ & $\mathrm{C}_{\mathrm{sw}}$ & $\mathrm{C}_{\text {meas }}$ & $\mathrm{C}_{\mathrm{sw}}$ \\
\hline \multicolumn{7}{|c|}{ Packer set at $936 \mathrm{mbsf}$} \\
\hline 1 & & $\begin{array}{r}158 \\
95\end{array}$ & $\begin{array}{l}157 \\
262\end{array}$ & $\begin{array}{l}20.6 \\
34.2\end{array}$ & $\begin{array}{l}3.87 \\
6.44\end{array}$ & $\begin{array}{l}0.51 \\
0.84\end{array}$ \\
\hline 2 & $\begin{array}{c}0.3 \\
*^{0} 0.1 \\
0.03\end{array}$ & $\begin{array}{r}1585 \\
955 \\
631\end{array}$ & & & & \\
\hline 3 & $\begin{array}{r}1.0 \\
{ }^{*} 0.3 \\
0.1\end{array}$ & $\begin{array}{l}5012 \\
1995 \\
1259\end{array}$ & $\begin{array}{r}3.5 \\
\frac{8.6}{13.6}\end{array}$ & 0.7 & & $\begin{array}{l}0.016 \\
0.040 \\
0.064\end{array}$ \\
\hline 4 & $\begin{array}{c}0.3 \\
*^{0} 0.1 \\
0.03\end{array}$ & $\begin{array}{r}1995 \\
1000 \\
631\end{array}$ & & 5.2 & & $\begin{array}{l}0.040 \\
0.080 \\
0.127\end{array}$ \\
\hline
\end{tabular}

Packer set at $1236 \mathrm{mbsf}$

$\begin{array}{lcrrrrr}5 & 0.1 & 5012 & 1.51 & 0.84 & 0.026 & 0.015 \\ & * 0.03 & 1995 & \underline{3.79} & 2.10 & \underline{0.066} & 0.036 \\ & 0.01 & 1585 & \underline{4.78} & 2.65 & \underline{0.083} & 0.046 \\ 6 & 0.3 & 3162 & 2.39 & 1.33 & 0.041 & 0.023 \\ & * 0.1 & 1412 & \underline{5.36} & 2.97 & \underline{0.093} & 0.052 \\ & 0.03 & 631 & 12.00 & 6.65 & \underline{0.208} & 0.115\end{array}$

${ }^{a}$ For each slug test, except the unreliable slug test 1 , calculations are presented for curve fits corresponding to three values of $\alpha$. Asterisks denote the values of $\alpha$ that yielded the best subjective fits of the slug test data to the $F(\alpha, \beta)$ function, which are shown in Figure 6. As discussed in the text, results from the outer values of $\alpha$ may be used to estimate the uncertainties in calculated permeabilities and transmissivities. However, the type-curve fits marked with asterisks and shown in Figure 6 were much better than for the surrounding values of $\alpha$, so the uncertainties plotted on Figure 8 were derived from the range in underlined permeability values.

b The parameter $t_{1}$ corresponds to the amounts that the type curves must be shifted to produce the best fits, as shown in Figure 6.

c Permeability $(k)$ and transmissivity $(T)$ are calculated from $t_{1}$ by $k=\mu C_{\mathrm{w}} V_{\mathrm{w}} / \pi b t_{1}$ and $T=V_{\mathrm{w}} C_{\mathrm{w}} \rho_{\mathrm{w}} g / \pi t_{1}$. Results are presented for two values of compressibility $C_{\mathrm{w}}$ the average measured values ( $C_{\text {meas }}$; Table 2$)$ and the tabulated value for seawater $\left(C_{\mathrm{sw}}\right)$ used by Anderson and Zoback (1982), Zoback and Anderson (1983), and Anderson et al. (1985a, 1985b) for slug tests shallower in the hole. As discussed in the text, the underlined results using the average measured value are more realistic and are shown in Figure 8.

meability and estimated porosity in the deeper extrusives and a better empirical relationship between permeability and porosity determined from electrical resistivity.

Given the uncertainties that arise because of the differences in compressibilities measured during Leg 111 and assumed by Anderson et al. (1985a, 1985b), the combined results simply do not resolve any possible differences in permeability among the deeper extrusives, the transition zone, and the $>500 \mathrm{~m}$ of sheeted dikes penetrated by Hole 504B. Nevertheless, these limitations do not compromise the primary conclusions of the studies of permeability in the hole: the only significantly permeable section is the upper $200 \mathrm{~m}$ of extrusives, and the remaining section, which consists of over $1 \mathrm{~km}$ of sealed extrusives and sheeted dikes, is much less permeable. The measurements conducted during Leg 111 show that the bulk permeability of the sheeted dikes in Hole 504B is about $5 \times 10^{-18}$ to $4 \times 10^{-17} \mathrm{~m}^{2}$, or three to four orders of magnitude less than the permeability of the uppermost extrusive basalts.

\section{ACKNOWLEDGMENTS}

The permeability measurements reported here would not have been possible without the expertise and hard work during both Legs 109 and 111 of the Sedco core technicians, W. Lee and T. McCown, who made the key adjustments necessary to make the go-devil seal properly during Leg 109. We also thank the captain, operations superintendent, and drill crew of the D/V JOIDES Resolution. Prior to Leg 109, the development of the packer had proceeded quickly, thanks to the enthusiasm and expertise of C. O. "Doc" Stokley of TAM International and the advice generously given by the ODP engineering staff. This report was improved after a careful review by S. H. Hickman. This study was supported by NSF grants OCE 85-13537 and OCE 88-00077.

\section{REFERENCES}

Alt, J. C., Honnorez, J., Laverne, C., and Emmermann, R., 1986. Hydrothermal alteration of a $1 \mathrm{~km}$ section through the upper oceanic crust, Deep Sea Drilling Project Hole 504B: mineralogy, chemistry, and evolution of seawater-basalt interactions. J. Geophys. Res., 91: $10,309-10,335$.

Alt, J. C., Laverne, C., and Muehlenbachs, K., 1985. Alteration of the upper oceanic crust: mineralogy and processes in Deep Sea Drilling Project Hole 504B, Leg 83. In Anderson, R. N., Honnorez, J., Becker, K., et al., Init. Repts. DSDP, 83: Washington (U.S. Govt. Printing Office), 217-241.

Anderson, R. N., Honnorez, J., Becker, K., Adamson, A. C., Alt, J. C., Emmermann, R., Kempton, P. D., Kinoshita, H., Laverne, C., Mottl, M. J., and Newmark, R. L., 1982. DSDP Hole 504B, the first reference section over $1 \mathrm{~km}$ through the oceanic crust. Nature, 300:589-594.

Anderson, R. N., and Zoback, M. D., 1982. Permeability, underpressures, and convection in the oceanic crust near the Costa Rica Rift, eastern equatorial Pacific. J. Geophys. Res., 87:2860-2868.

Anderson, R. N., Zoback, M. D., Hickman, S. H., and Newmark, R. L., 1985a. Permeability versus depth in the upper oceanic crust: in situ measurements in DSDP Hole 504B, eastern equatorial Pacific. $J$. Geophys. Res., 90:3659-3669.

1985 b. Permeability versus depth in the upper oceanic crust: in situ measurements in Deep Sea Drilling Project Hole 504B, eastern equatorial Pacific. In Anderson, R. N., Honnorez, J., Becker, K., et al., Init. Repts. DSDP, 83: Washington (U.S. Govt. Printing Office), 429-442.

Becker, K., 1985. Large-scale electrical resistivity and bulk porosity of the oceanic crust, Deep Sea Drilling Project Hole 504B, Costa Rica Rift. In Anderson, R. N., Honnorez, J., Becker, K., et al., Init. Repts. DSDP, 83: Washington (U.S. Govt. Printing Office), 419427.

1986. Special report: development and use of packers in ODP. JOIDES J., 12:51-57.

1988. A guide to ODP tools for downhole measurements. ODP Tech. Note, 10.

in press. Measurements of the permeability of the upper oceanic crust at Hole 395A, ODP Leg 109. In Detrick, R. S., Honnorez, J., Bryan, W. B., Juteau, T., et al., Proc. ODP, Sci. Results, 106/109: College Station, TX (Ocean Drilling Program).

Becker, K., Langseth, M. G., and Von Herzen, R. P., 1983a. Deep crustal geothermal measurements, Hole 504B, Deep Sea Drilling Project Legs 69 and 70. In Cann, J. R., Langseth, M. G., Honnorez, J., Von Herzen, R. P., White, S. M., et al., Init. Repts. DSDP, 69: Washington (U.S. Govt. Printing Office), 223-236.

Becker, K., Langseth, M. G., Von Herzen, R. P., and Anderson, R. N., 1983b. Deep crustal geothermal measurements, Hole 504B, Costa Rica Rift. J. Geophys. Res., 88:3447-3457.

Becker, K., Von Herzen, R. P., Francis, T.J.G., Anderson, R. N., Honnorez, J., Adamson, A. C., Alt, J. C., Emmermann, R., Kempton, P. D., Kinoshita, H., Laverne, C., Mottl, M. J., and Newmark, R. L., 1982. In situ electrical resistivity and bulk porosity of the oceanic crust, Costa Rica Rift. Nature, 300:594-598.

Bredehoeft, J. D., and Papadopulos, S. S., 1980. A method for determining the hydraulic properties of tight formations. Water Resour. Res., 16:223-238.

Bullard, E. C., 1954. The flow of heat through the floor of the Atlantic Ocean. Proc. R. Astron. Soc. London, Ser. A, 222:408-429.

Carslaw, H. S., and Jaeger, J. C., 1959. The Conduction of Heat in Solids: London (Oxford Univ. Press). 
Cooper, H. H., Jr., Bredehoeft, J. D., and Papadopulos, I. S., 1967. Response of a finite diameter well to an instantaneous charge of water. Water Resour. Res., 3:267-269.

Gartling, D. K., 1977. Convective heat transfer analysis by the finite element method. Comput. Methods Appl. Mech. Eng., 12:365-382.

Haimson, B. C., and Doe, T. W., 1983. State of stress, permeability, and fractures in the Precambrian granite of northern Illinois. J. Geophys. Res., 88:7355-7371.

Hickman, S. H., Langseth, M. G., and Svitek, J. F., 1984. In situ permeability and pore-pressure measurements near the Mid-Atlantic Ridge, Deep Sea Drilling Project Hole 395A. In Hyndman, R. D., Salisbury, M. H., et al., Init. Repts. DSDP, 78B: Washington (U.S. Govt. Printing Office), 699-708.

Neuzil, C. E., 1982. On conducting the modified 'slug' test in tight formations. Water Resour. Res., 18:439-441.
Papadopulos, S. S., Bredehoeft, J. D., and Cooper, H. H., 1973. On the analysis of 'slug test' data. Water Resour. Res., 9:1087-1089.

Parsons, R. W., 1966. Permeability of idealized fractured rock. J. Soc. Petrol. Eng., 6:126-136.

Zoback, M. D., and Anderson, R. N., 1983. Permeability, underpressures, and convection in the oceanic crust at Deep Sea Drilling Project Hole 504B. In Cann, J. R., Langseth, M. G., Honnorez, J., Von Herzen, R. P., White, S. M., et al., Init. Repts. DSDP, 69: Washington (U.S. Govt. Printing Office), 245-254.

Date of initial receipt: 11 January 1989

Date of acceptance: 9 February 1989

Ms 111B-156

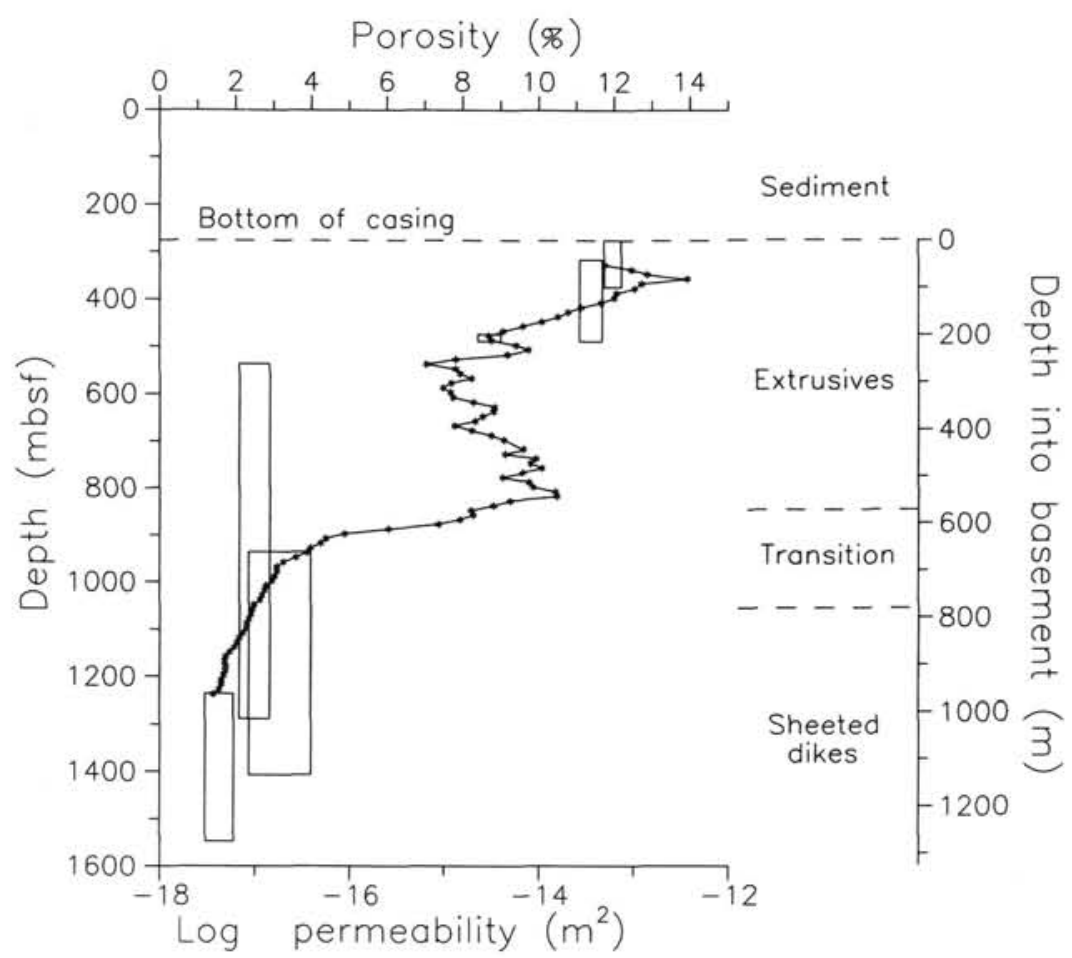

Figure 8. Bulk permeabilities (rectangles) measured through Leg 111 in Hole 504B, plotted with apparent bulk porosities (asterisks) estimated from large-scale resistivities. As in Figure 3, the vertical extents of the rectangles indicate the intervals over which average permeabilities were determined, and the horizontal extents indicate estimated uncertainties in the calculated permeabilities. Note that the arbitrary scaling between permeability and porosity has been changed slightly from that used in Figure 3, to bring the two data sets into better empirical alignment. 